\title{
Biological and physical forcing of carbonate chemistry in an upwelling filament off northwest Africa: Results from a Lagrangian study
}

\author{
Socratis Loucaides, ${ }^{1}$ Toby Tyrrell, ${ }^{1}$ Eric P. Achterberg, ${ }^{1}$ Ricardo Torres, ${ }^{2}$ \\ Philip D. Nightingale, ${ }^{2}$ Vassilis Kitidis, ${ }^{2}$ Pablo Serret, ${ }^{3}$ Malcolm Woodward, ${ }^{2}$ \\ and Carol Robinson ${ }^{4}$ \\ Received 25 September 2011; revised 6 June 2012; accepted 8 June 2012; published 3 August 2012.
}

[1] The Mauritanian upwelling system is one of the most biologically productive regions of the world's oceans. Coastal upwelling transfers nutrients to the sun-lit surface ocean, thereby stimulating phytoplankton growth. Upwelling of deep waters also supplies dissolved inorganic carbon (DIC), high levels of which lead to low calcium carbonate saturation states in surface waters, with potentially adverse effects on marine calcifiers. In this study an upwelled filament off the coast of northwest Africa was followed using drifting buoys and sulphur hexafluoride to determine how the carbonate chemistry changed over time as a result of biological, physical and chemical processes. The initial $\mathrm{pH}_{\text {tot }}$ in the mixed layer of the upwelled plume was 7.94 and the saturation states of calcite and aragonite were 3.4 and 2.2, respectively. As the plume moved offshore over a period of 9 days, biological uptake of DIC $\left(37 \mu \mathrm{mol} \mathrm{kg}^{-1}\right)$ reduced $\mathrm{pCO}_{2}$ concentrations from 540 to $410 \mu \mathrm{atm}$, thereby increasing $\mathrm{pH}_{\text {tot }}$ to 8.05 and calcite and aragonite saturation states to 4.0 and 2.7 respectively. The increase $\left(25 \mu \mathrm{mol} \mathrm{kg}^{-1}\right)$ in total alkalinity over the 9 day study period can be accounted for solely by the combined effects of nitrate uptake and processes that alter salinity (i.e., evaporation and mixing with other water masses). We found no evidence of significant alkalinity accumulation as a result of exudation of organic bases by primary producers. The ongoing expansion of oxygen minimum zones through global warming will likely further reduce the $\mathrm{CaCO}_{3}$ saturation of upwelled waters, amplifying any adverse consequences of ocean acidification on the ecosystem of the Mauritanian upwelling system.

Citation: Loucaides, S., T. Tyrrell, E. P. Achterberg, R. Torres, P. D. Nightingale, V. Kitidis, P. Serret, M. Woodward, and C. Robinson (2012), Biological and physical forcing of carbonate chemistry in an upwelling filament off northwest Africa: Results from a Lagrangian study, Global Biogeochem. Cycles, 26, GB3008, doi:10.1029/2011GB004216.

\section{Introduction}

\subsection{Ocean Acidification and Upwelling Systems}

[2] The atmospheric carbon dioxide $\left(\mathrm{CO}_{2}\right)$ concentration is currently approaching $400 \mathrm{ppm}$, a level unparalleled over the last 0.8 million years [Lüthi et al., 2008]. About a quarter of

\footnotetext{
${ }^{1}$ School of Ocean and Earth Science, National Oceanography Centre Southampton, University of Southampton, Southampton, UK.

${ }^{2}$ Plymouth Marine Laboratory, Plymouth, UK.

${ }^{3}$ Department of Ecology and Animal Biology, University of Vigo, Vigo, Spain UK.

${ }^{4}$ School of Environmental Sciences, University of East Anglia, Norwich,

Corresponding author: T. Tyrrell, School of Ocean and Earth Science, National Oceanography Centre Southampton, University of Southampton, Southampton SO14 3ZH, UK. (tt@noc.soton.ac.uk)

(C2012. American Geophysical Union. All Rights Reserved. 0886-6236/12/2011GB004216
}

the anthropogenic $\mathrm{CO}_{2}$ released during the last few decades has been taken up by the ocean [Canadell et al., 2007]. Following ocean uptake, $\mathrm{CO}_{2}$ forms carbonic acid which dissociates readily leading to a decrease in $\mathrm{pH}$ and carbonate ion $\left(\mathrm{CO}_{3}^{2-}\right)$ concentration, which determines the calcium carbonate $\left(\mathrm{CaCO}_{3}\right)$ saturation state $(\Omega)$ of the ocean. Atmospheric $\mathrm{CO}_{2}$ levels could potentially rise to $800 \mathrm{ppm}$ by the end of the century, resulting in a further decrease in $\mathrm{pH}$ of up to 0.3 units and a $50 \%$ reduction in the concentration of $\mathrm{CO}_{3}^{2-}$ and the saturation states of $\mathrm{CaCO}_{3}$ minerals [Orr et al., 2005]. The overall response of marine organisms to ocean acidification remains uncertain [Langer et al., 2006, 2009; Ries et al., 2009]. However, laboratory studies suggest that at least some species of marine calcifiers will be negatively affected [Comeau et al., 2009; Fabry et al., 2008; Kuffner et al., 2008; Langer et al., 2006].

[3] The surface ocean is generally oversaturated with respect to calcite and aragonite, the most common types of 
biogenic $\mathrm{CaCO}_{3}$. On a global scale, surface $\mathrm{CaCO}_{3}$ saturation states show a latitudinal gradient which roughly follows sea surface temperature (SST) distributions. This is mainly due to the fact that cold water can hold more $\mathrm{CO}_{2}$ (because of increased solubility) and that dissolved $\mathrm{CO}_{2}$ in most of the surface ocean is at near-equilibrium with the atmosphere [Opdyke and Wilkinson, 1993]. Calcium carbonate saturation states are therefore highest in low latitude waters and decline toward the poles. Low SST combined with high freshwater inputs [Yamamoto-Kawai et al., 2009] have defined polar oceans as ocean acidification "hot spots" which is why a large number of ocean acidification studies have focused on these regions [Anderson et al., 2010; Bates and Mathis, 2009; Chierici and Fransson, 2009; Comeau et al., 2009; Steinacher et al., 2009; Yamamoto-Kawai et al., 2009]. Recent evidence, however, suggests that the effects of ocean acidification can also be pronounced at lower latitude locations where cold, deep, $\mathrm{CO}_{2}$-rich water upwells to the surface ocean. Along the west coast of the U.S.A., for example, seasonal upwelling processes now bring waters undersaturated with respect to aragonite $\left(\Omega_{\mathrm{arag}}<1\right)$ to the surface over the continental shelf [Feely et al., 2008; Hauri et al., 2009]. Even though Pacific deep waters naturally hold higher concentrations of $\mathrm{CO}_{2}$, mainly from organic carbon mineralization, Feely et al. [2008] calculated that if the anthropogenic signal was to be removed from the $\mathrm{CO}_{2}$ content of the upwelled water, the aragonite saturation horizon would be $50 \mathrm{~m}$ deeper. As the $\mathrm{CaCO}_{3}$ saturation horizon continues to shoal in the next decades, upwelling areas will be among the first to experience the impacts of $\mathrm{CaCO}_{3}$ undersaturation.

[4] Although marginal seas are net exporters of organic carbon, their role in inorganic carbon cycling remains ambiguous [Gattuso et al., 1998]. This is because in these systems, and especially in upwelling areas, inorganic carbon cycling is driven by a combination of biological and physical processes including the production and remineralization of organic carbon and biogenic carbonates, upwelling of nutrients and dissolved inorganic carbon, and water mass mixing [Borges and Frankignoulle, 2001]. In such dynamic systems carbonate chemistry data from fixed time series stations falls short in distinguishing between biological and physical signals [Bakker et al., 1996; Borges and Frankignoulle, 1999; DeGrandpre et al., 1998; Friederich et al., 1995]. In contrast, Lagrangian studies, such as the one described here, allow for biological processes to be studied independently from physical processes (i.e., tidal advection, water mass mixing etc.). This study provides insight into the mechanisms and processes involved in inorganic carbon cycling in eastern boundary upwelling systems and along upwelling filaments.

[5] During the last two decades a number of studies have focused on inorganic carbon cycling in upwelling systems but mainly of the Pacific Ocean [Fassbender et al., 2011; Feely et al., 2008; Ianson et al., 2003; Ribas-Ribas et al., 2011; Torres et al., 2011; van Geen et al., 2000]. In contrast, very little carbonate chemistry data exists from the Atlantic Ocean except from the Benguela [Santana-Casiano et al., 2009] and Galician [Borges and Frankignoulle, 2001, 2002] upwellings. Upwelling systems are typically rich fishing grounds, and because of the ecological and socioeconomic importance of these waters, their response to ocean acidification must be addressed.

\subsection{The Mauritanian Upwelling Region}

[6] The Mauritanian upwelling region is one of the two major upwelling systems in the Atlantic Ocean and globally one of the most biologically productive ecosystems, supporting large commercial fisheries [Pauly and Christensen, 1995].

[7] The hydrography of the upper tropical northeast Atlantic Ocean is complex [Stramma et al., 2005]. Major currents in the area include the Canary Current (CC), which flows in a southwesterly direction from the Canary Islands. The upwelling of cold, nutrient-rich waters takes place along the coastline caused by alongshore wind stress. The position and intensity of the Mauritanian upwelling follows closely the seasonal variations in the intensity and spatial characteristics of the trade winds. During the winter, the trade winds are positioned furthest south between $10^{\circ} \mathrm{N}$ and $25^{\circ} \mathrm{N}$. During spring the wind system migrates northward and in summer is positioned between $20^{\circ} \mathrm{N}$ and $32^{\circ} \mathrm{N}$. In the region between $20^{\circ} \mathrm{N}$ and $25^{\circ} \mathrm{N}$ (the location of this study) the trade winds and associated upwelling remain strong and persistent throughout the year [Stramma et al., 2005].

[8] Here we describe the carbonate system dynamics within an upwelling filament in the Mauritanian upwelling area based on direct measurements of dissolved inorganic carbon (DIC) and total alkalinity (TA). Previous studies of biogeochemical dynamics in upwelling regions [Joint et al., 2001; Wilkerson and Dugdale, 1987] have utilized drifting buoys to track upwelled water. This method, however, has the limitation that one can never be certain that the drifting buoys remain within the upwelled plume. Buoys released together in patches of upwelled water often tend to follow tracks which diverge over time [D'Asaro, 2004], so it is uncertain if deployed buoys stay with the initial patch of water. In this study, the tracer sulphur hexafluoride $\left(\mathrm{SF}_{6}\right)$ was used to accurately follow the path of the upwelled water during its migration offshore and to constrain rates of horizontal and vertical mixing. The use of this tracer allowed a more accurate determination of the effects of upwelling on biogeochemical processes and carbonate chemistry.

\section{Methods}

[9] Cruise D338 took place in the period between April 15 and May 27, 2009, in the upwelling region off the coasts of Mauritania and Western Sahara (Figure 1) aboard the RRS Discovery as part of the UK SOLAS (Surface Ocean Lower Atmosphere Study) program. Here we detail the results from a Lagrangian study which involved the tracking of an upwelled patch in the period between April 22 and 30, 2009.

\subsection{Tracking the Filament}

[10] The course of an upwelled water mass was followed by releasing 5 drifter buoys and two deliberate tracers $\left(\mathrm{SF}_{6}\right.$ and ${ }^{3} \mathrm{He}$ ) at a location which, according to satellite SST data, was the center of intense upwelling. Full details of the dual tracer release technique can be found elsewhere [Nightingale et al., 2000]. The tracers were deployed at a constant rate at a depth of $5 \mathrm{~m}$ in the shape of a square spiral $(1 \times 0.8 \mathrm{~km})$ around the central drifter which was released the previous day (day 1). Additional drifters were deployed on each of the four corners of the initial $\mathrm{SF}_{6}$ patch. All drifters were 


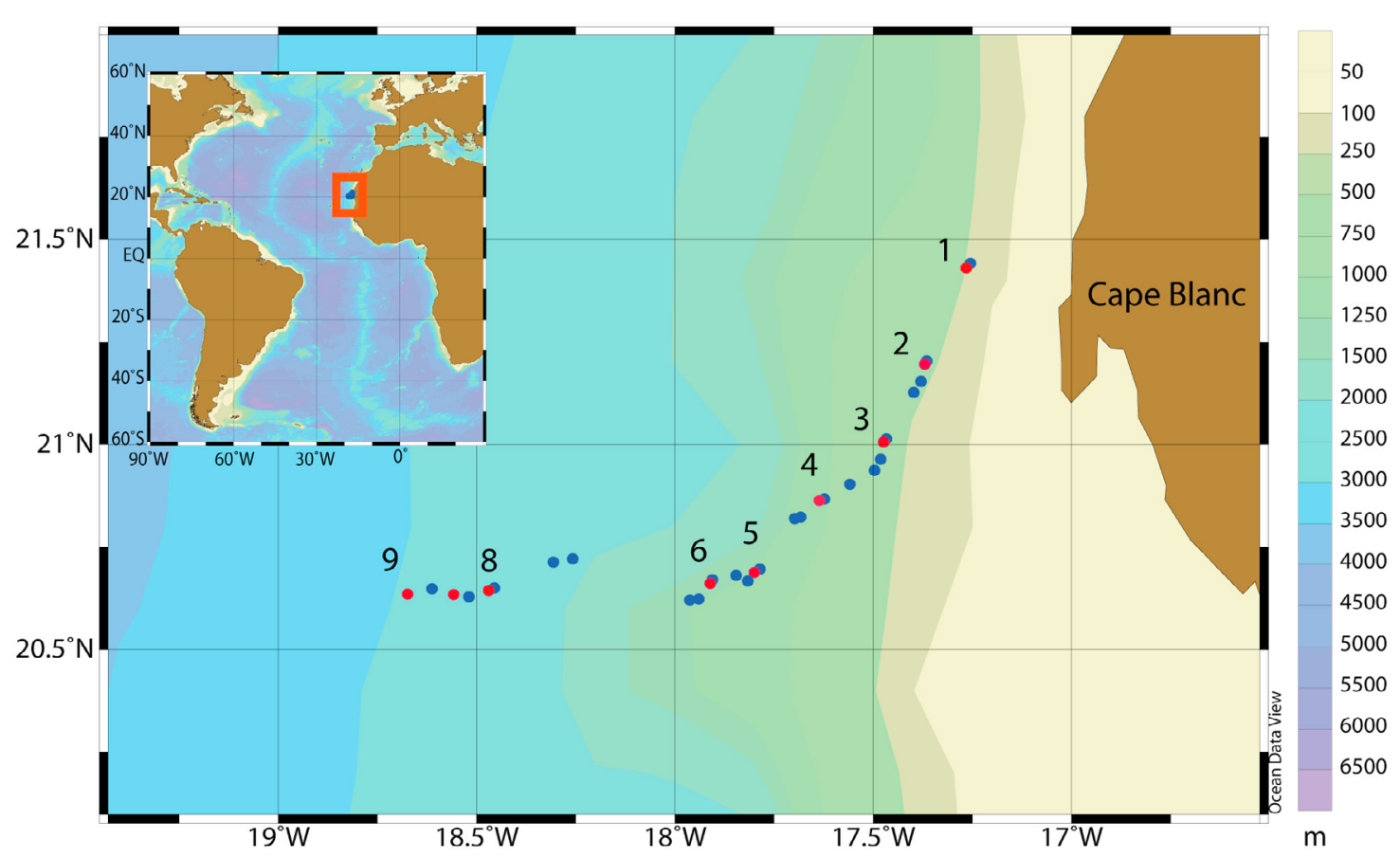

Figure 1. CTD sampling stations during the 9 day Lagrangian study. Stations at which DIC and TA samples were collected are marked in red. Numbers represent days, with day 1 being the day the central drifter was released.

equipped with ARGOS-GPS transmitters and were continuously tracked by the ship via RF communications. The concentration of $\mathrm{SF}_{6}$ in the mixed layer was measured via an automated gas chromatography system connected to the ship's underway seawater supply. Each night, the extent of the $\mathrm{SF}_{6}$ patch, and the location of the center of mass of the $\mathrm{SF}_{6}\left(\mathrm{SF}_{6} \mathrm{CM}\right)$ was determined. The ship relocated to this position each morning before commencing CTD deployments. If the distance between the position of the $\mathrm{SF}_{6} \mathrm{CM}$ and the central drifter was more than $1 \mathrm{~km}$, the central drifter was relocated to the new patch center position. $\mathrm{SF}_{6}$ concentrations were also measured in samples collected from the Niskin bottles (Ocean Test Equipment) mounted on the CTD rosette frame in order to verify that all CTD deployments occurred within the $\mathrm{SF}_{6}$ patch center.

\subsection{Carbonate Chemistry}

[11] Samples for DIC, TA and other analyses were collected using Niskin bottles mounted on a CTD rosette frame which was deployed within the upwelling filament as the ship tracked the $\mathrm{SF}_{6}$ patch and drifter buoys over the course of 9 days. In the subsequent sections, day 1 refers to the day the first station was sampled, which took place at the same time as the initial deployment of the central drifter. On day 2, carbonate chemistry sampling followed the deployment of $\mathrm{SF}_{6}$.

[12] Samples for DIC and TA measurements were collected in $250 \mathrm{~mL}$ borosilicate bottles, poisoned with mercuric chloride and sealed according to Dickson et al. [2007]. Total alkalinity and DIC were determined using a VINDTA 3C instrument (Marianda, Germany) which utilizes state of the art acidimetric and coulometric titrations for the measurements of TA and DIC, respectively. The precision of the instrument based on replicate measurements on the same batch of seawater was better than $2 \mu \mathrm{mol} \mathrm{kg}{ }^{-1}$ for both TA and DIC. The instrument was calibrated using certified reference materials (CRM) provided by Andrew Dickson (Scripps Institute of Oceanography). Certified reference materials were analyzed every 5-10 samples in order to frequently monitor the instrument's precision and accuracy. Other carbonate system parameters (i.e., $\mathrm{pH}_{\text {tot }}, \mathrm{pCO}_{2}, \Omega_{\mathrm{cal}}, \Omega_{\mathrm{arag}}$ ) for each sample were calculated using the $\mathrm{CO}_{2} \mathrm{SYS}$ program [Lewis and Wallace, 1998; Pierrot et al., 2006] from DIC and TA, while taking into account nutrient concentrations, salinity and in situ temperature. The dissociation constants used were those reported by Mehrbach et al. [1973] and refitted by Dickson and Millero [1987] and the solubility products of calcite and aragonite were those determined by Mucci [1983].

\subsection{Other Biogeochemical Parameters}

[13] Depth profiles of salinity, temperature, dissolved oxygen and fluorescence were determined using an array of sensors mounted on the CTD rosette frame. Salinity and temperature were measured by a Seabird 911 + CTD sensor. The salinity values were calibrated against discrete samples taken from the Niskin bottles and measured onboard with a salinometer (Autosal, Guildline). Chlorophyll $a$ was calculated from fluorescence measurements made by an Aquatracka (Chelsea Instruments Ltd) fluorometer. The sensor was calibrated against onboard measurements of chlorophyll $a$ according to Strickland and Parsons [1968]. Oxygen values were measured with a Seabird SBE 32 sensor. Oxygen data were calibrated with samples taken from the Niskin bottles and analyzed by Winkler titration (analytical precision in the order of $0.05 \mu \mathrm{mol} \mathrm{kg}^{-1}$ for $n=4-6$ ) as described 


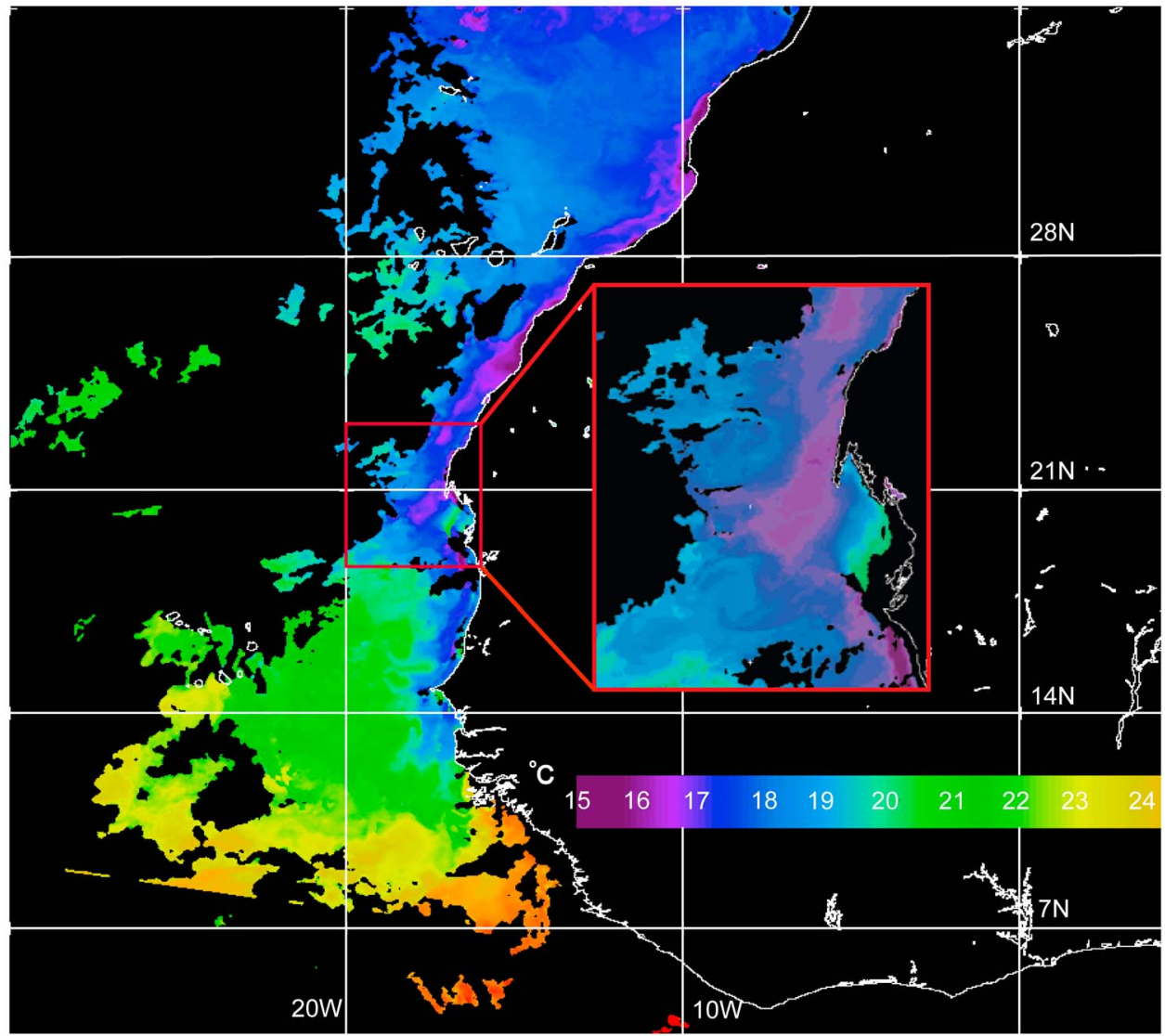

Figure 2. Advanced Very High Resolution Radiometer-Sea Surface Temperature (AVHRR-SST) satellite image showing the upwelling of colder water off northwest Africa (region near $21^{\circ} \mathrm{N}$ is enlarged) on April 22, 2009. Image provided by NEODAAS, PML, UK.

in Robinson et al. [2009]. Oxygen concentrations were used to calculate the Apparent Oxygen Utilization (AOU), which equates to the difference between the measured $\mathrm{O}_{2}$ concentration and the saturation concentration of $\mathrm{O}_{2}$ at in situ temperature [García and Gordon, 1992].

[14] Nutrients (silicate, phosphate and nitrate) were measured colorimetrically using a Bran and Luebbe AAIII segmented flow autoanalyzer [Woodward and Rees, 2001]. Samples were collected from the Niskin bottles into acid washed, "aged," $60 \mathrm{~mL}$ high density polyethylene bottles and analyzed as soon as possible, with no samples being stored or frozen. Nutrient clean sampling and handling techniques were carefully observed throughout. Detection limits were $0.04 \mu \mathrm{mol} \mathrm{kg}{ }^{-1}$ for silicate and phosphate and $0.05 \mu \mathrm{mol} \mathrm{kg}^{-1}$ for nitrate with analytical precision of $2 \%$ for replicate samples $(n=4)$.

\subsection{Calculation of Mixed Layer Depth}

[15] The depth of the mixed layer was calculated using a density criterion $\left(\Delta \sigma_{\mathrm{t}}=0.125\right)$ as described by Levitus [1982]. By using a density as opposed to a temperature criterion, changes in salinity can also be accounted for in the calculation of the mixed layer depth. The value of 0.125 used for the density criterion corresponds to a temperature change of $0.55^{\circ} \mathrm{C}$ or a salinity change of 0.15 for the salinity and temperature ranges of the waters sampled.

\section{Results}

[16] The use of drifter buoys in combination with $\mathrm{SF}_{6}$ allowed us to successfully track the movement of the patch of upwelled water for several days as it moved offshore. Therefore, data collected during the Lagrangian study and presented in this manuscript provides more reliable information on the biological and physical processing of inorganic carbon following upwelling.

[17] Following several days of intense winds, intensification in upwelling off the west coast of Cape Blanc led to the formation of an upwelled filament which extended $200 \mathrm{~km}$ offshore (Figure 2). The location of the upwelling center (between 20 and $21^{\circ} \mathrm{N}$ ) agreed with the seasonal patterns of the Mauritanian upwelling system [Stramma et al., 2005; Van Camp et al., 1991]. The cold water mass was transported in a southwesterly/westerly direction (see Figure 1) over the subsequent 9 days. The trajectory of the filament was clearly visible in satellite SST images and the satelliteobserved track agreed well with the track followed by the buoys and $\mathrm{SF}_{6}$. 
onshore offshore
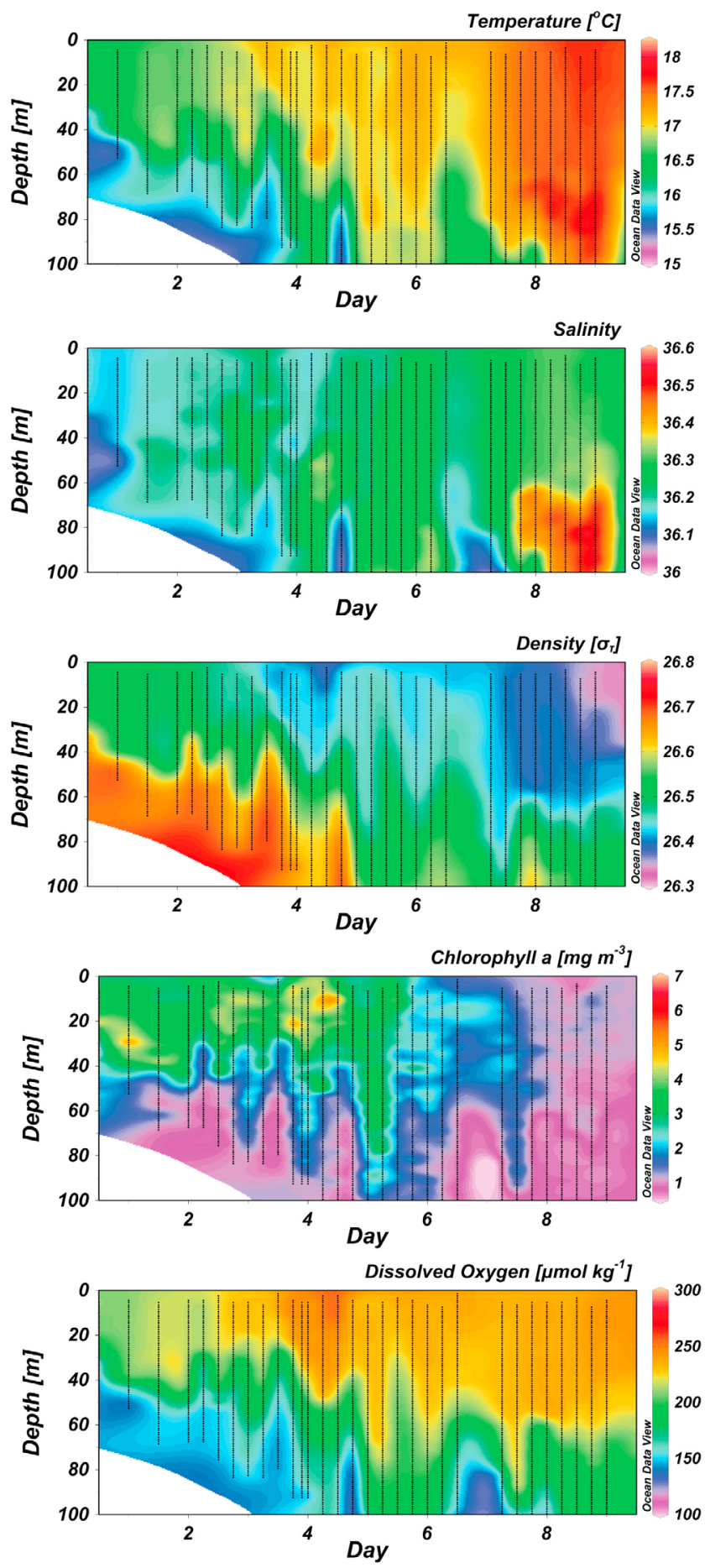

Figure 3. Depth profiles of temperature, salinity, density, chlorophyll $a$, and dissolved oxygen versus time in the upwelled filament as determined using sensors mounted on the CTD rosette frame. Salinity, chlorophyll and dissolved oxygen concentrations were calibrated against samples taken from the rosette mounted Niskin bottles and analyzed onboard. Black dots show CTD sampling depths.
[18] The temperature of the upwelled water was $16.5^{\circ} \mathrm{C}$; about $2^{\circ} \mathrm{C}$ lower than that of the surrounding waters (Figure 2). During the first three overnight surveys of the $\mathrm{SF}_{6}$ patch (days 2-4), both the patch and the drifters were found to have moved in a south-southwesterly direction at a speed averaging $40 \mathrm{~cm} \mathrm{~s}^{-1}$. The patch experienced a clockwise rotation due to the horizontal shear of the background flow, and gradually increased in size. After day 4, as the patch was transported away from the continental shelf, the mixed layer deepened (Figures 3 and 4d). The central drifter was relocated after the first overnight sampling (day 2) as the estimated $\mathrm{SF}_{6} \mathrm{CM}$-drifter distance was $1.1 \mathrm{~km}$. The central drifter maintained a distance of less than $1 \mathrm{~km}$ from the $\mathrm{SF}_{6}$ $\mathrm{CM}$ on day 3 but was again relocated on day 4 when the distance increased to $1.8 \mathrm{~km}$. By that point the sampled patch extended over a distance of more than $14 \mathrm{~km}$. The following overnight sampling revealed a rapid elongation of the patch due to an increase in the horizontal flow shear associated with the northern edge of the upwelling filament. The patch had increased to a length of more than $40 \mathrm{~km}$ and the $\mathrm{SF}_{6} \mathrm{CM}$ was not readily identifiable in the overnight mapping surveys. The rate of $\mathrm{SF}_{6} \mathrm{CM}$-drifter separation during the previous 3 days was less than $1 \mathrm{~km} \mathrm{day}^{-1}$. If the same separation rate was maintained until the end of the study, the final distance between the $\mathrm{SF}_{6} \mathrm{CM}$ and the central drifter would have been of the order of $3 \mathrm{~km}$, similar to the original patch size. After day 5 the central drifter was therefore used as the patch center.

[19] Figure 3 shows depth profiles of temperature, salinity, density, chlorophyll and dissolved oxygen concentrations determined by the CTD sensors along the Lagrangian transect. Average mixed layer temperature increased steadily over time (by more than $1^{\circ} \mathrm{C}$ over the 9 days) as the water mass migrated offshore (Figure 4a). Nitrate concentrations decreased from a maximum of $9.3 \mu \mathrm{mol} \mathrm{kg}^{-1}$ to a minimum of $4.7 \mu \mathrm{mol} \mathrm{kg}^{-1}$ on day 8 , phosphate decreased from $0.67 \mu \mathrm{mol} \mathrm{kg} \mathrm{kg}^{-1}$ to $0.38 \mu \mathrm{mol} \mathrm{kg} \mathrm{kg}^{-1}$ and silicate from $2.7 \mu \mathrm{mol} \mathrm{kg}^{-1}$ to $1.0 \mu \mathrm{mol} \mathrm{kg}{ }^{-1}$ (Figure $4 \mathrm{~b}$ ). The mixed layer depths along the transect ranged between 30 and $107 \mathrm{~m}$ (Figure 4c).

[20] Chlorophyll $a$ concentrations were high during the first 6 days but decreased to levels below $2 \mathrm{mg} \mathrm{m}^{-3}$ after day 6 and below $1 \mathrm{mg} \mathrm{m}^{-3}$ after day 8 (Figure 3). The highest chlorophyll $a$ concentrations $\left(\sim 6 \mathrm{mg} \mathrm{m}^{-3}\right)$ were encountered at day 1 at a depth of $30 \mathrm{~m}$ and around day 4 in the top $25 \mathrm{~m}$ (Figure 3). The phytoplankton bloom observed during the first days of the study was dominated by diatoms (C. Widdicombe, personal communication, 2011), and may have crashed due to silicate depletion (Figure 4b). Dissolved oxygen saturation in the mixed layer increased from $85 \%$ on day 1 to $102 \%$ by day 4 and remained close to saturation ( 240 $\mu \mathrm{mol} \mathrm{kg}^{-1}$; Figure 3) thereafter.

[21] Average DIC concentrations in the mixed layer (Figure 4d) decreased during the Lagrangian study with highest levels shortly after upwelling $\left(2168 \mu \mathrm{mol} \mathrm{kg}^{-1}\right)$ and lowest levels during the last days of the study $\left(2131 \mu \mathrm{mol} \mathrm{kg}^{-1}\right)$. Averaged mixed-layer DIC around day 8.5 was higher than both the preceding and subsequent measurements, but measured nitrate was also higher at this time. Average mixed layer TA concentrations increased during the study (Figures 5 and 9) with minimum levels on 

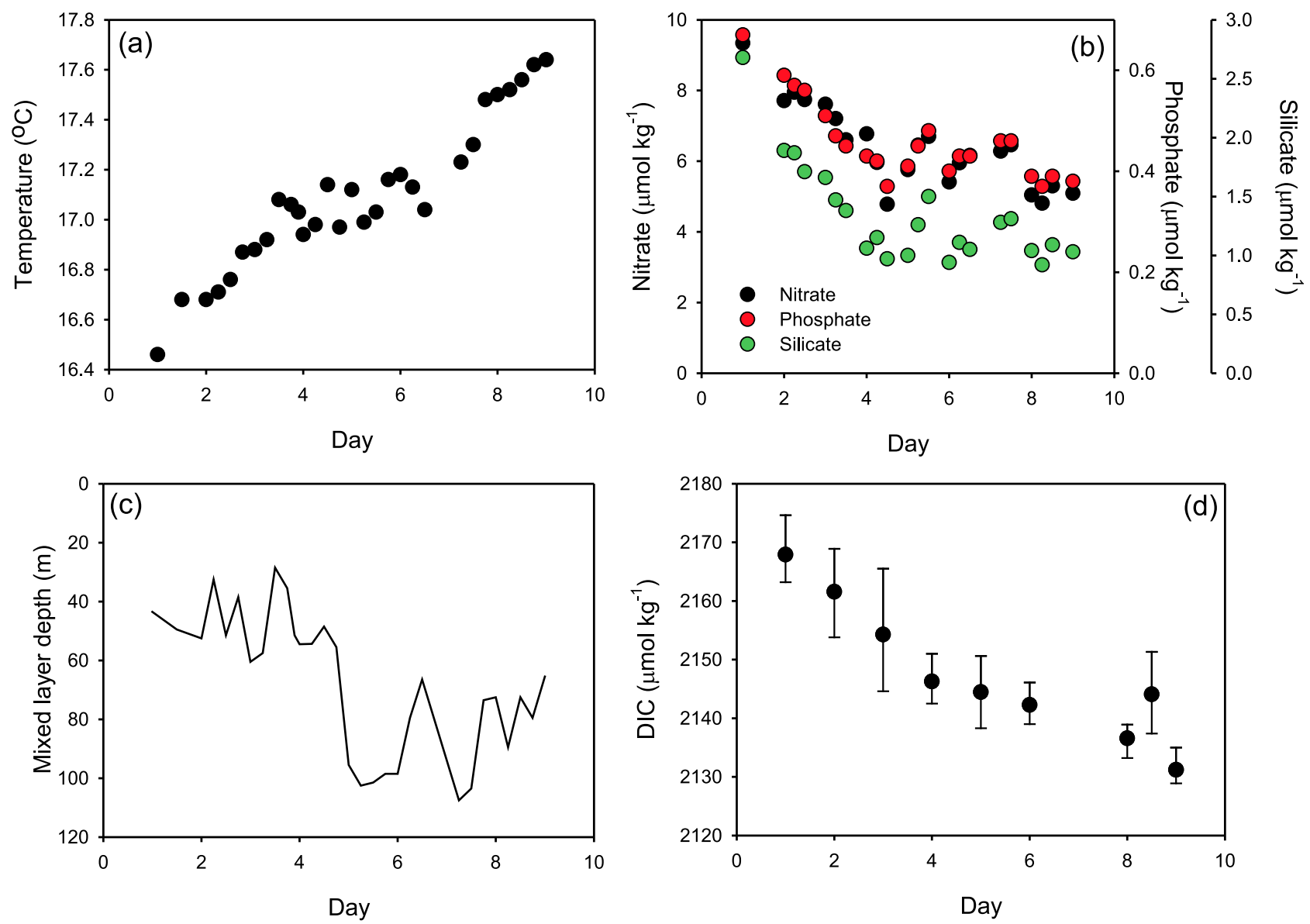

Figure 4. Mixed layer (a) average temperatures, (b) nutrient concentrations, (c) mixed layer depth, and (d) DIC concentrations, at each CTD station sampled during the Lagrangian study. Bars in Figure 4d represent the range of DIC values in the mixed layer.
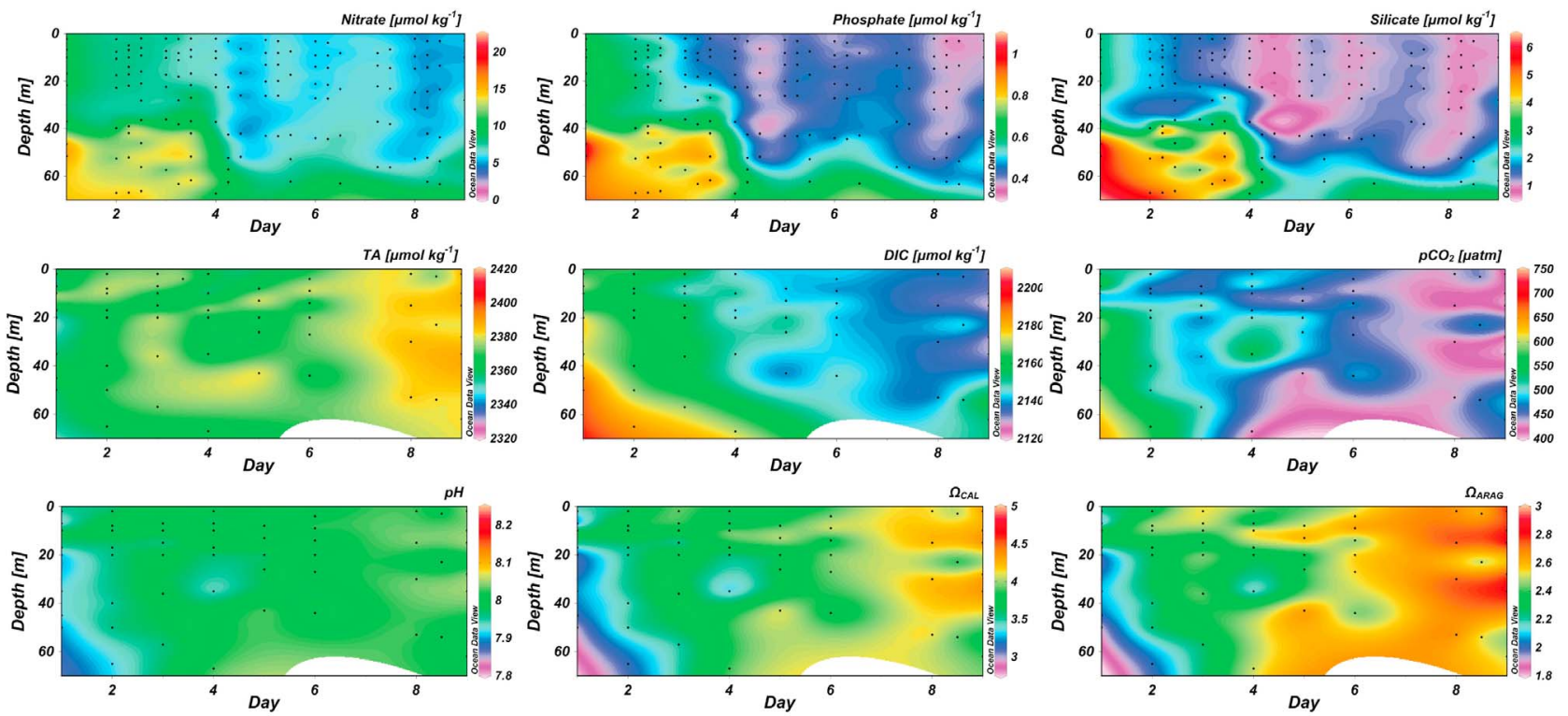

Figure 5. Depth profiles of nitrate, phosphate, silicate, TA and DIC concentrations versus time in the upwelled filament. $\mathrm{pCO}_{2}, \mathrm{pH}_{\mathrm{tot}}$, and the saturation states of calcite and aragonite were calculated from TA, DIC and nutrient concentrations using CO2SYS. Black dots show CTD sampling depths. 

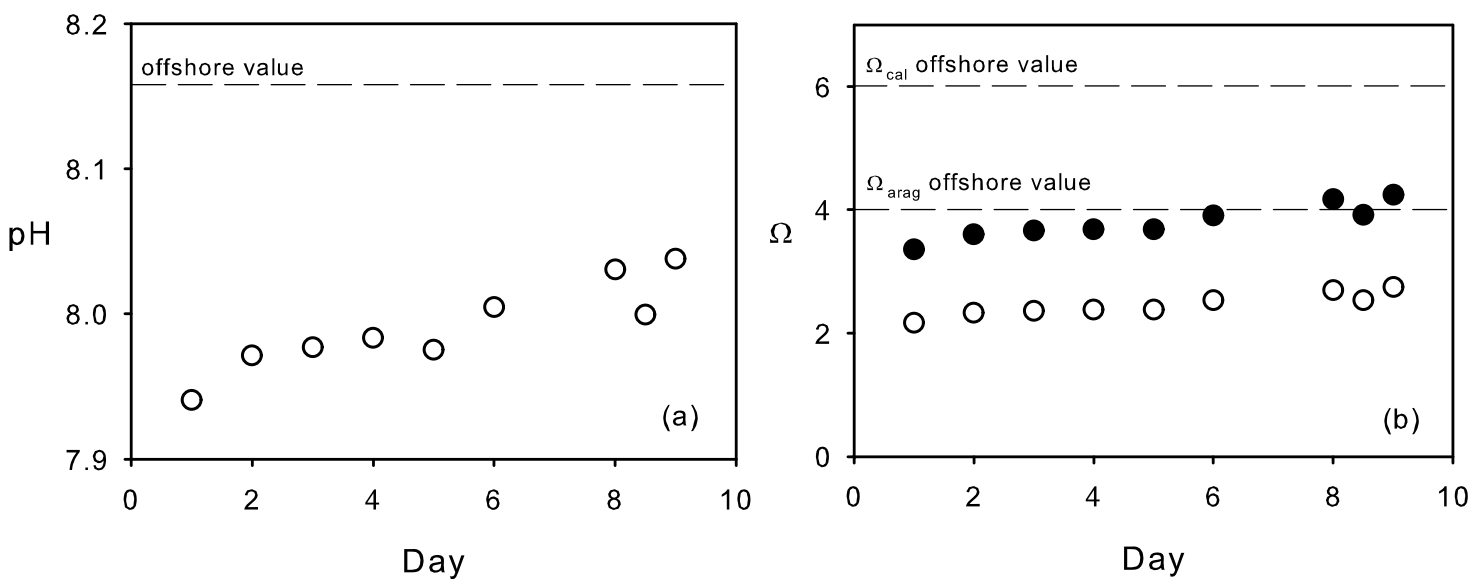

Figure 6. Surface mixed layer average values of (a) $\mathrm{pH}_{\mathrm{tot}}$ and (b) aragonite (open circles) and calcite (filled circles) saturation states during the Lagrangian study.

day $1\left(2360 \mu \mathrm{mol} \mathrm{kg} \mathrm{kg}^{-1}\right)$ and maximum values on the last day $\left(2385 \mu \mathrm{mol} \mathrm{kg}{ }^{-1}\right)$. The $\mathrm{pCO}_{2}$ of the upwelled water, as calculated from DIC and TA, was initially close to $540 \mu \mathrm{atm}$ but subsequently decreased, reaching $400-450 \mu \mathrm{atm}$ by days 8 and 9 (Figure 5). High $\mathrm{pCO}_{2}$ concentrations corresponded to low $\mathrm{pH}_{\text {tot }}$ values, which were as low as 7.94 in the mixed layer on day 1 (Figures 5 and 6a). After day $6, \mathrm{pH}_{\text {tot }}$ values gradually increased to 8.05 . On day 1 , saturation states of calcite and aragonite were 3.2 and 2.1 respectively in the mixed layer. Saturation states increased gradually to 4.0 and 2.7 for calcite and aragonite, respectively, during occupation of the last station (Figure 6b).

\section{Discussion}

\subsection{Temporal Changes in the Physicochemical Properties of the Upwelled Plume}

[22] The salinity of the upwelled plume increased only slightly (36.1-36.3) throughout the study (Figure 3), suggesting that freshwater inputs and evaporation were insignificant over the short duration of the observations. The temperature of the upwelled patch increased with time but remained relatively low $\left(<18^{\circ} \mathrm{C}\right.$; Figures 3 and 4 ; in agreement with earlier work [Mittelstaedt, 1991]) compared to waters further offshore which ranged between 22 and $25^{\circ} \mathrm{C}$.

[23] Within the course of about one day after its addition, the $\mathrm{SF}_{6}$ mixed vertically to fully occupy the surface mixed layer (50 m deep, Figure $4 \mathrm{c}$ ). The $\mathrm{SF}_{6}$ concentrations in the patch center then followed an exponential decrease over time (Figure 7). This trend indicates that we consistently sampled the center of the patch, with the decrease in $\mathrm{SF}_{6}$ concentration due to horizontal spread of this tracer controlled by Fickian diffusion [Nightingale et al., 2000]. As discussed below, horizontal mixing and entrainment is not thought to lead to large biogeochemical fluxes in the biogeochemical variables. We can therefore assume that any changes in biogeochemical variables observed are either driven by internal dynamics (biogeochemical processes) taking place within the sampled patch of water or are driven by vertical exchanges.

[24] Observed vertical diffusivity across the pycnocline during the study, measured using a free-falling shear microstructure profiler (ISW Wassermesstechnik MSS90
[Prandke et al., 2000]), ranged between $10^{-6}$ and $10^{-4} \mathrm{~m}^{2} \mathrm{~s}^{-1}$ with an average of $10^{-5} \mathrm{~m}^{2} \mathrm{~s}^{-1}$ (from $\sim 130$ deployments). Associated vertical diffusive fluxes were therefore too low to explain any of the observed changes in DIC and TA. While diffusive fluxes were small, entrainment due to mixed layer deepening took place on about day 4 (Figure 4c). Despite the entrainment, reflected by a small recovery in nutrient concentrations (Figure $4 \mathrm{~b}$ ) and a slight drop in temperature (Figure 4a) after day 4, DIC concentrations continued to decrease, although at a reduced rate (Figure 4d). Outgassing of $\mathrm{CO}_{2}$ from the patch contributed to a minor reduction in DIC concentrations; a maximum reduction of $5 \mu \mathrm{mol} \mathrm{kg} \mathrm{kg}^{-1}$ DIC over the 9 day period was calculated using the largest air-sea $\mathrm{CO}_{2}$ gradient, from day 1.

[25] We have investigated the importance of biogeochemical fluxes associated with any horizontal mixing and consequent entrainment of out-of-patch waters, and expect them to be small. Nitrate and phosphate concentrations reported for the region north of the Cape Verde Islands (800 km west of our study area) were at nanomolar levels

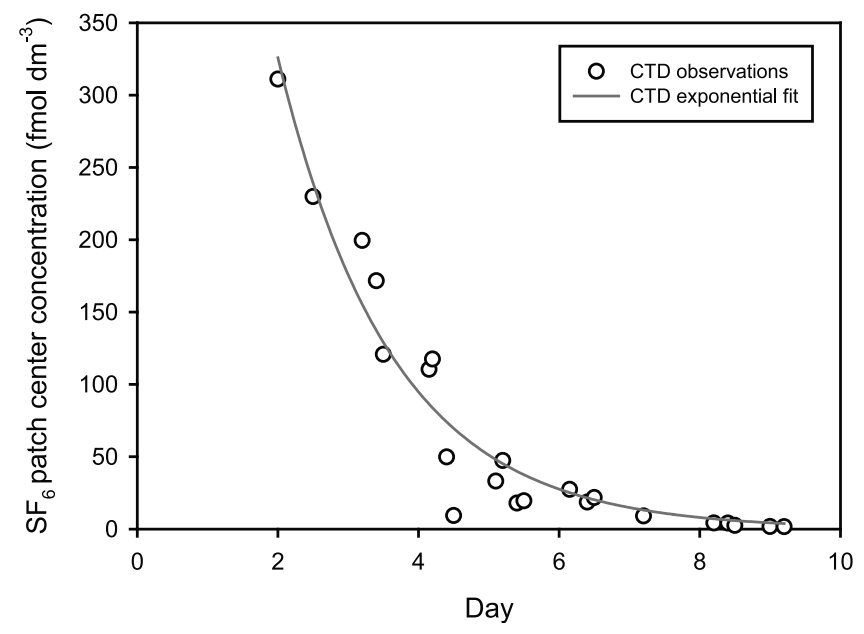

Figure 7. Averaged mixed layer $\mathrm{SF}_{6}$ concentrations from discretely sampled CTD mounted Niskin bottles (circles) during the Lagrangian study. An exponential curve has been fitted to the discrete data. 

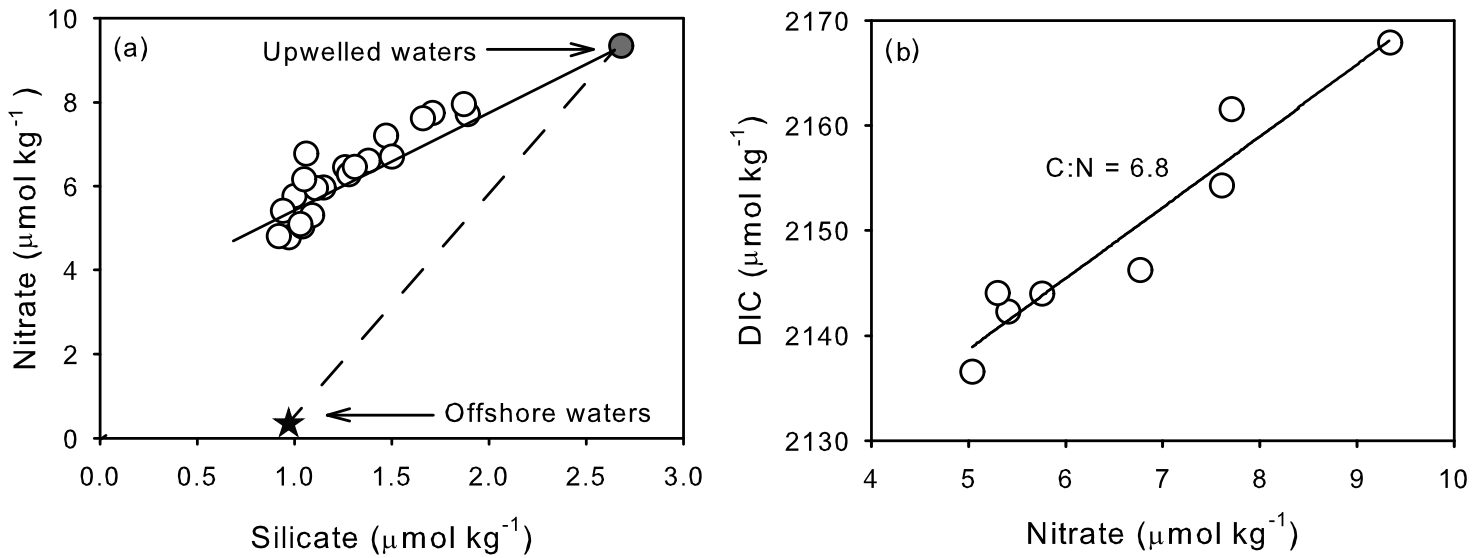

Figure 8. (a) Average mixed layer nitrate versus silicate concentrations observed in the upwelled patch during the study. Dashed line represents nitrate to silicate ratios that would result from the mixing of freshly upwelled (red circle) and offshore nutrient depleted waters (black star). (b) Average mixed layer DIC versus nitrate concentrations. Best fit line corresponds to a C:N ratio equal to $6.8 \pm 0.8$.

(C. Dumousseaud et al., Control of the carbonate system by upwelling and respiration in the (sub)-tropical Northeast Atlantic Ocean, manuscript in preparation, 2012). Dilution of the patch with similar nutrient depleted waters would have led to temporal patterns in the nutrients that were very different from those observed. This is illustrated in Figure 8a, using nitrate and silicate concentrations as an example. Mixing of waters in the filament with nutrient depleted waters would have led to nitrate and silicate concentrations in the upwelled patch varying along a line connecting the two end-members (Figure 8a). In this case the first end-member is the upwelled water on day 1 (Nitrate $=9.3 \mu \mathrm{mol} \mathrm{kg}{ }^{-1}$; Silicate $=2.7 \mu \mathrm{mol} \mathrm{kg}^{-1}$ ) and the other the offshore nutrient depleted waters $\left(\mathrm{N} \sim 0 \mu \mathrm{mol} \mathrm{kg}{ }^{-1}\right.$, $\left.\mathrm{Si} \sim 1 \mu \mathrm{mol} \mathrm{kg}^{-1}\right)$. However, observed nitrate and silicate concentrations did not lie along this mixing line, demonstrating that the decline in nutrient concentrations owed more to biological uptake than to dilution with offshore waters. Furthermore, the Redfield type DIC:N uptake ratio (Figure $8 \mathrm{~b}$ ) strongly supports a scenario where changes in nutrient concentrations were caused by phytoplankton uptake rather than by mixing with low nutrient waters. Therefore, it is more likely that the effects of horizontal mixing were minimal because waters entrained into the patch had also been recently upwelled, and had a similar chemical composition to the patch water.

[26] Mixing only induces a net flux in the presence of a concentration gradient. The variations in the carbonate chemistry in the upwelled patch were therefore dominated by internal processes rather than horizontal or vertical exchanges.

\subsection{Effect of Biological Productivity on the Carbonate Chemistry of the Upwelling Plume}

4.2.1. DIC Drawdown and $\mathrm{CaCO}_{3}$ Saturation Increase by Primary Productivity

[27] The DIC concentration of the upwelled water was $2168 \mu \mathrm{mol} \mathrm{kg}^{-1}$ when first sampled (Figure 5), which is near the upper limit of DIC values reported for North Atlantic Central Waters (NACW) (Dumousseaud et al., manuscript in preparation, 2012). North Atlantic Central Waters occupy the top 700-800 m of the water column north of the Cape Verde frontal zone, which extends southwest from Cape Blanc to the Cape Verde Islands. The decrease in DIC over the 9 day period (Figures $4 \mathrm{c}$ and 5 ) was proportional to that of nitrate (Figure 8a) with a DIC: $\mathrm{NO}_{3}$ uptake ratio of $6.8 \pm 0.8$ (error represents the standard deviation of the slope of the regression line) which is close to the Redfield ratio of 6.63. This is consistent with DIC in the mixed layer being controlled primarily by biological uptake into soft tissues and not being significantly affected by calcification or dissolution of $\mathrm{CaCO}_{3}$, or vertical exchanges.

[28] During this Lagrangian study, calculated levels of $\mathrm{pCO}_{2}$ within the upwelled plume decreased from about $540 \mu \mathrm{atm}$ on day 1 to slightly above $400 \mu \mathrm{atm}$ on day 9 . These values are similar to those directly observed in the same area during the Eumeli-4 cruise, between May and June 1992, which reached $500 \mu \mathrm{atm}$ just south of Cape Blanc [Copin-Montégut and Avril, 1995]. Values of $\mathrm{pCO}_{2}$ are significantly lower further offshore, in the proximity of the Cape Verde Islands the (Dumousseaud et al., manuscript in preparation, 2012), and in the open tropical and subtropical Atlantic where surface $\mathrm{pCO}_{2}$ rarely exceeded $400 \mu \mathrm{atm}$ [Takahashi et al., 2002].

[29] Concentrations of $\mathrm{pCO}_{2}$ and $\mathrm{DIC}$ in the upwelled water decreased with time spent at the surface, primarily due to phytoplankton uptake. This consequently resulted in an increase in $\mathrm{CaCO}_{3}$ saturation states, as shown in Figure 6b; the values of $\Omega_{\text {cal }}$ and $\Omega_{\text {arag }}$ increased from day 1 to day 9 by 0.8 and 0.6 , respectively, up to values of about 4.0 and 2.7 by day 9. Similar mechanisms have been observed off the coast of northern California [Torres et al., 2011], in the northern South China Sea [Cao et al., 2011], along the Belgian coast [Borges and Gypens, 2010], in the North Pacific [Feely et al., 1988], in the Chukchi Sea [Bates et al., 2009] and in the Norwegian Sea [Findlay et al., 2008] where seasonal enhancement of calcite and aragonite saturation states is caused by high rates of primary production [Merico et al., 2006]. Although $\mathrm{CaCO}_{3}$ saturation states in the mixed layer were enhanced by primary productivity, they remained well below values recorded in the proximity of the Cape Verde Islands $\left(\Omega_{\mathrm{cal}}=6 ; \Omega_{\mathrm{ar}}=4\right.$ (Dumousseaud et al., manuscript in preparation, 2012)) and values calculated for the pelagic 


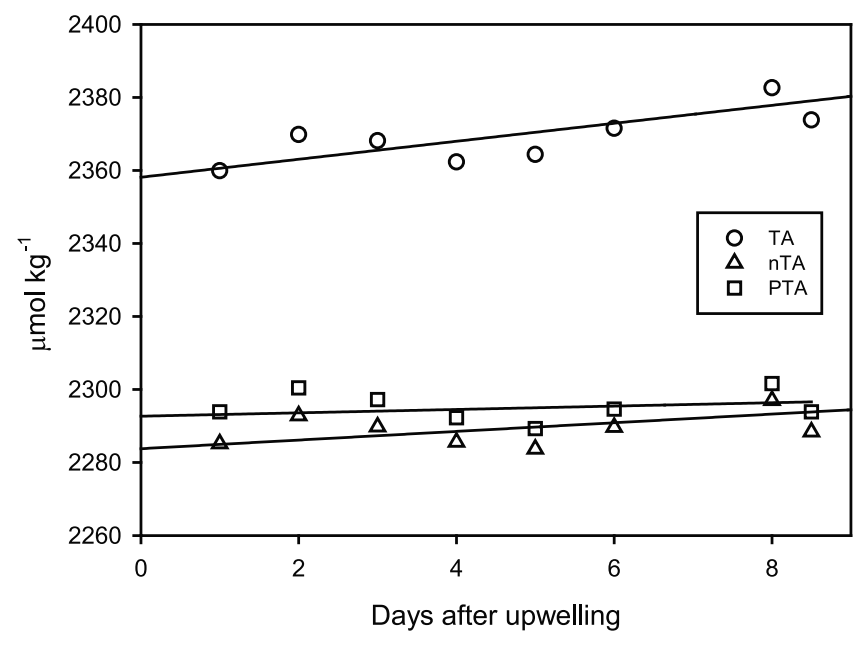

Figure 9. Evolution of mixed layer average concentrations of TA, nTA, and PTA in the upwelled plume over the course of the study (see text for calculation and definition of each parameter). Regression analysis gives slopes for $\mathrm{TA}=2.5 \pm 0.5, \mathrm{nTA}=1.18 \pm 0.5$, and PTA $=0.5 \pm 0.5$ $\mu \mathrm{mol} \mathrm{kg} \mathrm{kgy}^{-1}$ (errors represent the standard deviation of the slope).

tropical and subtropical Atlantic Ocean $\left(\Omega_{\text {cal }} \sim 5 ; \Omega_{\text {ar }} \sim 3\right.$ [Caldeira and Wickett, 2005]). It can be expected that additional primary production, fuelled by the $5 \mu \mathrm{mol} \mathrm{kg}^{-1}$ of $\mathrm{NO}_{3}$ still remaining at the end of the study, subsequently raised $\Omega$ toward offshore values.

\subsubsection{Effect of the Phytoplankton Bloom on the TA Within the Filament}

[30] Total alkalinity values observed in the freshly upwelled plume (average of $2360 \mu \mathrm{mol} \mathrm{kg}{ }^{-1}$ ) were within ranges reported for the NACW (Dumousseaud et al., manuscript in preparation, 2012) and close to values $\left(\sim 2380 \mu \mathrm{mol} \mathrm{kg}{ }^{-1}\right)$ measured about $300 \mathrm{~km}$ offshore from our study area [SolerAristegui, 2002]. We initially considered four different candidate explanations for the increase over time of TA in the upwelled plume (Figure 9; slope $=2.5 \pm 0.5 \mu \mathrm{mol} \mathrm{kg}^{-1} \mathrm{~d}^{-1}$ ): a) evaporation or mixing with higher salinity waters, b) nitrate uptake which increased TA in a $1: 1$ ratio, c) $\mathrm{CaCO}_{3}$ dissolution which increased TA in a 1:2 ratio (2 moles of TA released for every mole of $\mathrm{CaCO}_{3}$ dissolved), and d) generation of organic alkalinity associated with high levels of primary production [Kim et al., 2006; Kim and Lee, 2009].

[31] The influence of evaporation and/or mixing can be corrected for by normalizing TA (nTA) to a salinity of 35 [Millero et al., 1998]. This correction removed part of the observed increase in TA over the course of the study as shown in Figure 9 (slope of best fit line for nTA $=1.18 \pm$ $0.5 \mu \mathrm{mol} \mathrm{kg} \mathrm{kg}^{-1}$ ). Potential alkalinity (PA) was used to correct TA for changes in nitrate concentration, in addition to correcting for the effects of evaporation or mixing [Brewer and Goldman, 1976]. PA is calculated using:

$$
P A=\left(T A+\left[N O_{3}\right]\right) \times \frac{35}{S}
$$

where TA is the total alkalinity and $\mathrm{S}$ is the salinity. The effect of phosphate and sulphate uptake by phytoplankton on TA was negligible and therefore excluded from the PA calculations. Potential alkalinity was near constant during the course of the study, as shown in Figure 9 (slope of best fit line for $\mathrm{PA}=0.4 \pm 0.5 \mu \mathrm{mol} \mathrm{kg} \mathrm{kg}^{-1} \mathrm{~d}^{-1}$ ) which suggests that the observed increase in TA can be accounted for solely by the combined effect of nitrate uptake and processes that alter salinity. On the other hand, it is possible that organic alkalinity was being actively generated but simultaneously consumed by bacteria (in the process of feeding on DOM) or, coincidentally, exactly counterbalanced by removal of alkalinity due to calcification. Coccolithophore numbers measured during the study, however, never exceeded 100 cells $\mathrm{mL}^{-1}$ (G. Tarran, personal communication, 2011). Assuming these are mostly small coccolithophores such as Emiliania huxleyi, and hence maximum calcification rates are on the order of $9.6 \mathrm{pg} \mathrm{C}$ cell $^{-1}$ day $^{-1}$ [Balch et al., 1992], then the total drawdown of TA would be less than $2 \mu \mathrm{mol} \mathrm{kg}{ }^{-1}$ over a period of 9 days.

[32] There has been a strong interest in processes that could account for large inconsistencies between measured and calculated carbonate system parameters (i.e., $\mathrm{pCO}_{2}$ measured and $\mathrm{pCO}_{2}$ calculated from TA and DIC) reported in recent studies [Hoppe et al., 2010; Koeve et al., 2011]. One such process is the generation of alkalinity associated with dissolved organic matter, which is not incorporated in the standard theoretical TA framework [Dickson, 1981; Wolf-Gladrow et al., 2007]. Axenic culture experiments suggest that relevant amounts (between 40 and $70 \mu \mathrm{mol} \mathrm{kg}^{-1}$ ) of this 'organic alkalinity' can be generated by the exponential growth of certain diatom (Chaetoceros curvisetus, Skeletonema costatum) and dinoflagellate (Prorocentrum minimum) species [Kim and Lee, 2009]. As in cultures, phytoplankton also proliferate exponentially in recently upwelled waters due to favorable light and nutrient conditions, and so upwelling systems are an obvious place to look for evidence of organic alkalinity generation. In their cultures, Kim and Lee [2009] found that during exponential phytoplankton growth, organic alkalinity was produced at a rate of $0.3-0.6 \mu \mathrm{mol}$ for every $\mu$ mole of nitrate consumed. In our case, however, the uptake of nitrate during the 9 day study was only $4 \mu \mathrm{mol} \mathrm{kg}{ }^{-1}$. Based on the findings of Kim and Lee [2009] the associated increase in TA over the 9 days would therefore be less than, or close to, the measurement uncertainty $\left(2 \mu \mathrm{mol} \mathrm{kg}{ }^{-1}\right)$ of our TA method and therefore difficult to detect. Furthermore, such low concentrations of organic alkalinity would only lead to minor errors (i.e. $<1 \%$ for $\mathrm{pCO}_{2}$ ) in the calculations of the carbonate system from TA and another parameter.

[33] Although this study was not specifically designed to measure the generation of organic alkalinity or dissolved organic matter during the phytoplankton bloom proliferation, our data suggest that despite the intense primary production within the upwelling filament [Beale et al., 2010], organic alkalinity accumulation did not contribute significantly to TA. The increasing alkalinity is satisfactorily accounted for through nitrate uptake and water mass mixing alone, and the best fit line for potential alkalinity against time is statistically indistinguishable from a flat line with a zero slope (Figure 9). The slight positive slope is driven principally by just one data point (the measurement on day 8), without which the best fit line would have a negative slope of $0.5 \mu \mathrm{mol} \mathrm{kg}^{-1} \mathrm{~d}^{-1}$. Between days 2 and 4, when chlorophyll levels are at their highest (Figure 3 ) and nitrate is being strongly drawn down 


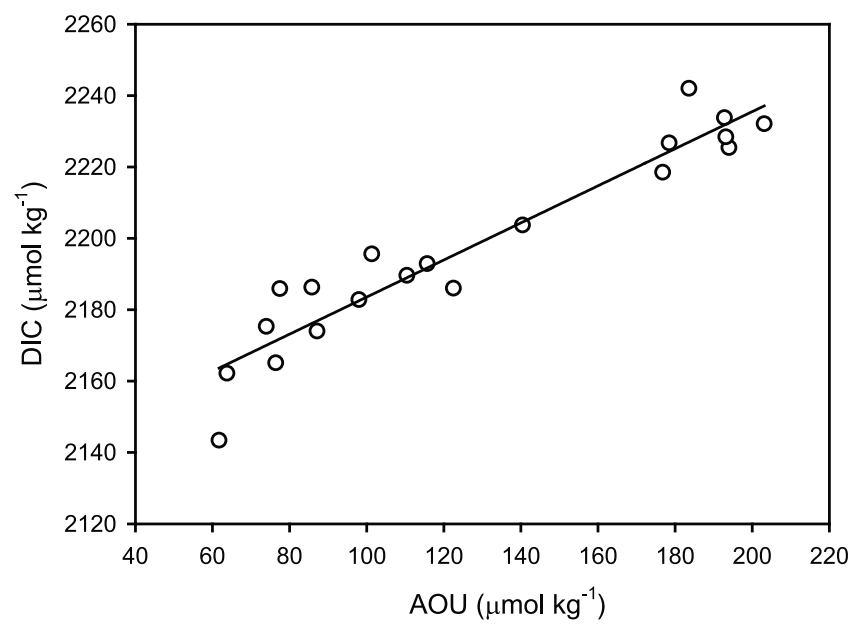

Figure 10. Correlation between DIC and AOU in waters below the mixed layer. $\left(\mathrm{r}^{2}=0.91\right)$; DIC:AOU $=0.51 \pm 0.04$.

(Figure 4b), PA is observed to decline rather than to increase (Figure 9). Therefore, our data suggests that the rate of organic alkalinity accumulation in the upwelling plume was either negligible or low. If the contribution of organic alkalinity is low even in this highly productive environment, then it is unlikely to be important elsewhere in the open ocean.

\subsection{Effect of Biological Productivity on the Carbonate} Chemistry of Sub-surface Waters

\subsubsection{Decline in $\mathrm{CaCO}_{3}$ Saturation States Through the} Aerobic Decomposition of Organic Matter

[34] In deep waters, the production of DIC is closely tied to the consumption of oxygen through microbial respiration. This explains the strong positive correlation observed between DIC and AOU (Figure 10) for all samples collected below the mixed layer depth up to a maximum depth of $800 \mathrm{~m}\left(\mathrm{r}^{2}=0.91, \mathrm{p}<0.0001, \mathrm{n}=20\right)$ with a best fit least squares regression of $\mathrm{DIC}=0.51 \mathrm{AOU}+2132$. The slope of 0.51 is in close agreement with the DIC:AOU ratio of 0.50 reported for remineralization into the shallower subsurface layers of the North Atlantic Ocean [Omta et al., 2011] and for the depth range 100-4000 $\mathrm{m}$ in the subtropical and tropical northeast Atlantic Ocean (DIC:AOU $=0.57$ (Dumousseaud et al., manuscript in preparation, 2012)). It is, however, much lower than the lower limit (0.62) of the carbon to oxygen remineralization ratio estimated for the deep ocean $(>400 \mathrm{~m})$ by Anderson and Sarmiento [1994]. Lower DIC:AOU ratios are associated with remineralization of labile and nitrogenrich organic matter (e.g., amino acids); DIC:AOU ratios between 0.48 and 0.625 are associated with short chained compounds with 4-5 carbon atoms in shallower waters, and higher DIC:AOU ratios are due to remineralization of more recalcitrant organic matter (e.g., carbohydrates; DIC:AOU ratio of 1) in deeper waters [Thomas, 2002].

[35] Carbon dioxide produced during plankton respiration dissolves in water to form carbonic acid. The dissociation of carbonic acid shifts the carbonate speciation so that $\mathrm{pH}$ and the saturation states of $\mathrm{CaCO}_{3}$ decline (Figure 11). Similar mechanisms involving reduction of the calcium carbonate saturation states through the remineralization of vertically transported organic matter have been reported for subsurface waters of the North Pacific [Feely et al., 1988], the Chukchi Sea [Bates et al., 2009] and the Lower St. Lawrence Estuary [Mucci et al., 2011].

4.3.2. The Northeast Atlantic Oxygen Minimum Zone and Its Effect on the Carbonate Chemistry of the Mauritanian Upwelling

[36] Oxygen concentrations at depths between 150 and $800 \mathrm{~m}$ were below $100 \mu \mathrm{mol} \mathrm{kg}^{-1}$ [Rees et al., 2011]. These low concentrations are consistent with the presence of the tropical northeast Atlantic oxygen minimum zone (OMZ), which results from the high rates of organic matter remineralization below the euphotic zone and the relatively slow ventilation rates in the area [Stramma et al., 2005, 2008a]. DIC concentrations within the oxygen minimum zone were the highest observed throughout the study area $\left(2240 \mu \mathrm{mol} \mathrm{kg}^{-1}\right)$ consistent with the increased degradation of organic matter and generation of $\mathrm{CO}_{2}$ at those depths.

[37] Despite the close proximity of the tropical northeast Atlantic OMZ to the upwelling area, the link between the two systems is weak [Glessmer et al., 2009]. The modeling study by Glessmer et al. [2009] suggested that currently only about $1 \%$ of the Mauritanian upwelling waters originate in the OMZ. It has been demonstrated, however, that strengthened stratification and reduced ventilation due to warming has led to a rapid expansion of OMZs [Stramma et al., 2008b, 2009].
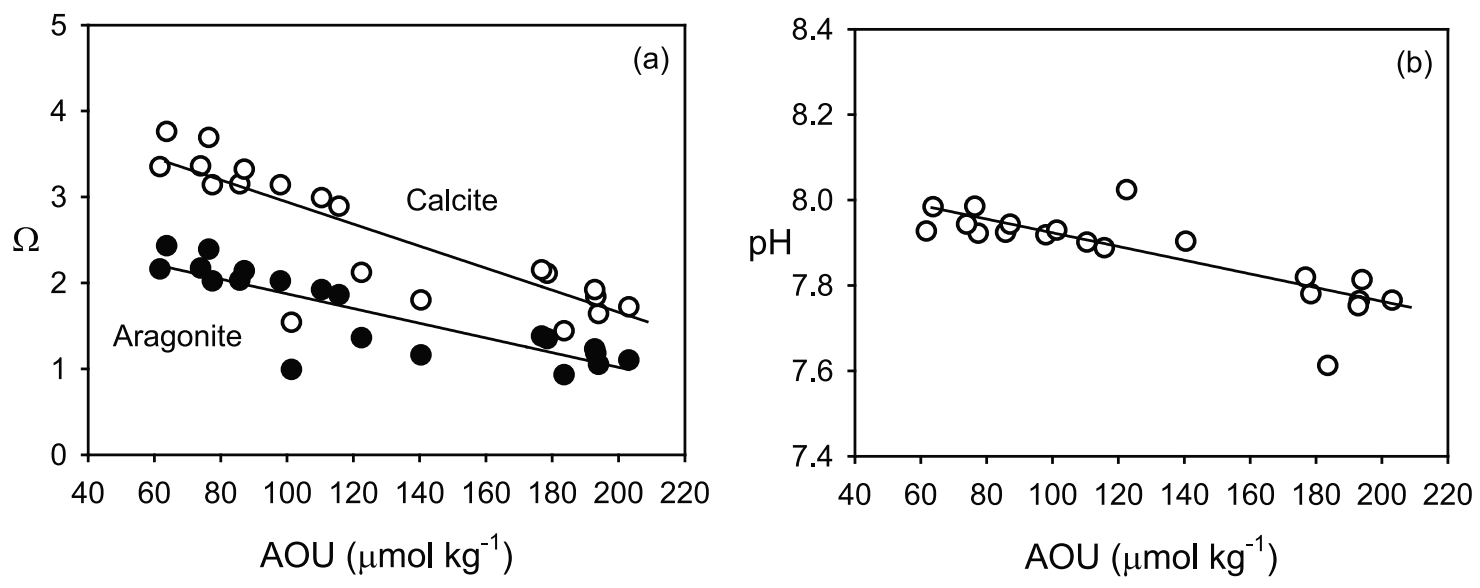

Figure 11. (a) Aragonite and calcite saturation states and (b) $\mathrm{pH}_{\text {tot }}$ versus apparent oxygen utilization (AOU) for depths below the mixed layer. 
It can thus be expected that global warming will further reduce $\mathrm{CaCO}_{3}$ saturation states in OMZs and increase their contribution to eastern boundary upwelling systems.

\section{Conclusions}

[38] The upwelling of $\mathrm{CO}_{2}$-rich waters along the $\mathrm{NW}$ African shelf leads initially to low saturation states of $\mathrm{CaCO}_{3}$ in surface waters $\left(\Omega_{\text {cal }}=3.4, \Omega_{\text {arag }}=2.2\right)$, well below averages for these latitudes. Marine plankton in upwelling ecosystems are likely to face challenges related to $\mathrm{CaCO}_{3}$ undersaturation much sooner than in other ecosystems at similar latitudes. Therefore, upwelling ecosystems can be considered as ocean acidification "hot spots," and the potential impacts on marine life, especially calcifiers, must be evaluated.

[39] Following the initial upwelling, uptake of carbon by phytoplankton acts to decrease DIC and consequently increase saturation states of $\mathrm{CaCO}_{3}$. In contrast, in sub-surface waters, remineralization of sinking organic matter generates $\mathrm{CO}_{2}$ which acts to increase DIC and suppress saturation states of $\mathrm{CaCO}_{3}$.

[40] Upwelling systems are an obvious place to study organic alkalinity generation due to the high rates of primary productivity in recently upwelled waters. Despite evidence of high primary production during our study, the rate of organic alkalinity accumulation was negligible. In eastern boundary OMZs, oxygen minima are associated with maximum $\mathrm{pCO}_{2}$ levels and minimum $\mathrm{CaCO}_{3}$ saturation states. Reduced ventilation of mid waters caused by global warming will lead to further expansion of these oceanic "dead zones" through deoxygenation. This would reduce $\mathrm{CaCO}_{3}$ saturation states to even lower values in the sub-surface waters that upwell onto the shelf of NW Africa, amplifying the consequences of ocean acidification.

[41] Acknowledgments. We would like to thank all of the scientists involved in the ICON experiment especially John Stephens, Malcolm Liddicoat and Ian Brown for help with $\mathrm{SF}_{6}$ deployment and tracking, and carbonate chemistry sample collection. We would also like to thank PML scientists Claire Widdicombe and Glen Tarran for providing information on the phytoplankton community. We thank all the officers and crew of RRS Discovery. This work was funded by the UK NERC via research grant NE/C517176/2 awarded to Carol Robinson and via Theme 2 of Oceans 2025. Additional funds were provided by the Marie Curie Initial Training Network CALMARO (Calcification by Marine Organisms) supported by funding under the Seventh Framework Programme of the European Community via a research fellowship to Socratis Loucaides.

\section{References}

Anderson, L. A., and J. L. Sarmiento (1994), Redfield ratios of remineralization determined by nutrient data analysis, Global Biogeochem. Cycles, 8(1), 65-80, doi:10.1029/93GB03318.

Anderson, L. G., T. Tanhua, G. Björk, S. Hjalmarsson, E. P. Jones, S. Jutterström, B. Rudels, J. H. Swift, and I. Wåhlstöm (2010), Arctic Ocean shelf-basin interaction: An active continental shelf $\mathrm{CO}_{2}$ pump and its impact on the degree of calcium carbonate solubility, Deep Sea Res., Part I, 57(7), 869-879, doi:10.1016/j.dsr.2010.03.012.

Bakker, D. C. E., H. J. W. de Baar, and H. P. J. de Wilde (1996), Dissolved carbon dioxide in Dutch coastal waters, Mar. Chem., 55(3-4), 247-263, doi:10.1016/S0304-4203(96)00067-9.

Balch, W. M., P. M. Holligan, and K. A. Kilpatrick (1992), Calcification, photosynthesis and growth of the bloom-forming coccolithophore, Emiliania huxleyi, Cont. Shelf Res., 12(12), 1353-1374, doi:10.1016/ 0278-4343(92)90059-S.

Bates, N. R., and J. T. Mathis (2009), The Arctic Ocean marine carbon cycle: Evaluation of air-sea $\mathrm{CO}_{2}$ exchanges, ocean acidification impacts and potential feedbacks, Biogeosciences, 6(11), 2433-2459, doi:10.5194/ bg-6-2433-2009.
Bates, N. R., J. T. Mathis, and L. W. Cooper (2009), Ocean acidification and biologically induced seasonality of carbonate mineral saturation states in the western Arctic Ocean, J. Geophys. Res., 114, C11007, doi:10.1029/2008JC004862.

Beale, R., P. S. Liss, and P. D. Nightingale (2010), First oceanic measurements of ethanol and propanol, Geophys. Res. Lett., 37, L24607, doi:10.1029/2010GL045534.

Borges, A. V., and M. Frankignoulle (1999), Daily and seasonal variations of the partial pressure of $\mathrm{CO}_{2}$ in surface seawater along Belgian and southern Dutch coastal areas, J. Mar. Syst., 19(4), 251-266, doi:10.1016/S09247963(98)00093-1

Borges, A. V., and M. Frankignoulle (2001), Short-term variations of the partial pressure of $\mathrm{CO}_{2}$ in surface waters of the Galician upwelling system, Prog. Oceanogr., 51(2-4), 283-302, doi:10.1016/S0079-6611(01) 00071-4.

Borges, A. V., and M. Frankignoulle (2002), Aspects of dissolved inorganic carbon dynamics in the upwelling system off the Galician coast, J. Mar. Syst., 32(1-3), 181-198, doi:10.1016/S0924-7963(02)00031-3.

Borges, A. V., and N. Gypens (2010), Carbonate chemistry in the coastal zone responds more strongly to eutrophication than ocean acidification, Limnol. Oceanogr., 55(1), 346-353, doi:10.4319/lo.2010.55.1.0346.

Brewer, P. G., and J. C. Goldman (1976), Alkalinity changes generated by phytoplankton growth, Limnol. Oceanogr., 21(1), 108-117, doi:10.4319/ lo.1976.21.1.0108.

Caldeira, K., and M. E. Wickett (2005), Ocean model predictions of chemistry changes from carbon dioxide emissions to the atmosphere and ocean, J. Geophys. Res., 110, C09S04, doi:10.1029/2004JC002671.

Canadell, J. G., C. Le Quéré, M. R. Raupach, C. B. Field, E. T. Buitenhuis, P. Ciais, T. J. Conway, N. P. Gillett, R. A. Houghton, and G. Marland (2007), Contributions to accelerating atmospheric $\mathrm{CO}_{2}$ growth from economic activity, carbon intensity, and efficiency of natural sinks, Proc. Natl. Acad. Sci. U. S. A., 104(47), 18,866-18,870, doi:10.1073/pnas. 0702737104

Cao, Z. M., M. H. Dai, N. Zheng, D. L. Wang, Q. Li, W. D. Zhai, F. F. Meng, and J. P. Gan (2011), Dynamics of the carbonate system in a large continental shelf system under the influence of both a river plume and coastal upwelling, J. Geophys. Res., 116, G02010, doi:10.1029/ 2010JG001596.

Chierici, M., and A. Fransson (2009), Calcium carbonate saturation in the surface water of the Arctic Ocean: Undersaturation in freshwater influenced shelves, Biogeosciences, 6(11), 2421-2431, doi:10.5194/bg-62421-2009.

Comeau, S., G. Gorsky, R. Jeffree, J. L. Teyssié, and J. P. Gattuso (2009), Impact of ocean acidification on a key Arctic pelagic mollusc (Limacina helicina), Biogeosciences, 6(9), 1877-1882, doi:10.5194/bg-6-18772009.

Copin-Montégut, C., and B. Avril (1995), Continuous $\mathrm{pCO}_{2}$ measurements in surface water of the northeastern tropical Atlantic, Tellus, Ser. B, 47 86-92, doi:10.1034/j.1600-0889.47.issue1.9.x.

D'Asaro, E. A. (2004), Lagrangian trajectories on the Oregon shelf during upwelling, Cont. Shelf Res., 24(13-14), 1421-1436, doi:10.1016/j. csr.2004.06.003.

DeGrandpre, M. D., T. R. Hammar, and C. D. Wirick (1998), Short-term $p \mathrm{CO}_{2}$ and $\mathrm{O}_{2}$ dynamics in California coastal waters, Deep Sea Res., Part II, 45(8-9), 1557-1575, doi:10.1016/S0967-0645(98)80006-4.

Dickson, A. G. (1981), An exact definition of total alkalinity and a procedure for the estimation of alkalinity and total inorganic carbon from titration data, Deep Sea Res., Part I, 28(6), 609-623, doi:10.1016/0198-0149 (81)90121-7.

Dickson, A. G., and F. J. Millero (1987), A comparison of the equilibrium constants for the dissociation of carbonic acid in seawater media, Deep Sea Res., Part I, 34(10), 1733-1743, doi:10.1016/0198-0149(87)90021-5.

Dickson, A. G., C. L. Sabine, and J. R. Christian (2007), Guide to best practices for ocean $\mathrm{CO}_{2}$ measurements, PICES Spec. Publ., 3, 191 pp., North Pac. Mar. Sci. Organ., Sidney, B. C., Canada.

Fabry, V. J., B. A. Seibel, R. A. Feely, and J. C. Orr (2008), Impacts of ocean acidification on marine fauna and ecosystem processes, ICES J. Mar. Sci., 65(3), 414-432, doi:10.1093/icesjms/fsn048.

Fassbender, A. J., C. L. Sabine, R. A. Feely, C. Langdon, and C. W. Mordy (2011), Inorganic carbon dynamics during northern California coastal upwelling, Cont. Shelf Res., 31(11), 1180-1192, doi:10.1016/j. csr.2011.04.006.

Feely, R. A., R. H. Byrne, J. G. Acker, P. R. Betzer, C.-T. A. Chen, J. F. Gendron, and M. F. Lamb (1988), Winter-summer variations of calcite and aragonite saturation in the northeast Pacific, Mar. Chem., 25(3), 227-241, doi:10.1016/0304-4203(88)90052-7.

Feely, R. A., C. L. Sabine, J. M. Hernandez-Ayon, D. Ianson, and B. Hales (2008), Evidence for upwelling of corrosive "acidified" water onto the 
continental shelf, Science, 320(5882), 1490-1492, doi:10.1126/science. 1155676.

Findlay, H. S., T. Tyrrell, R. G. J. Bellerby, A. Merico, and I. Skjelvan (2008), Carbon and nutrient mixed layer dynamics in the Norwegian Sea, Biogeosciences, 5(5), 1395-1410, doi:10.5194/bg-5-1395-2008.

Friederich, G. E., P. G. Brewer, R. Herlien, and F. P. Chavez (1995), Measurement of sea surface partial pressure of $\mathrm{CO}_{2}$ from a moored buoy, Deep Sea Res., Part I, 42(7), 1175-1186, doi:10.1016/0967-0637(95)00044-7.

García, H. E., and L. I. Gordon (1992), Oxygen solubility in seawater: Better fitting equations, Limnol. Oceanogr., 37(6), 1307-1312, doi:10.4319/ lo.1992.37.6.1307

Gattuso, J. P., M. Frankignoulle, and R. Wollast (1998), Carbon and carbonate metabolism in coastal aquatic ecosystems, Annu. Rev. Ecol. Syst., 29, 405-434.

Glessmer, M. S., C. Eden, and A. Oschlies (2009), Contribution of oxygen minimum zone waters to the coastal upwelling off Mauritania, Prog. Oceanogr., 83(1-4), 143-150, doi:10.1016/j.pocean.2009.07.015.

Hauri, C., N. Gruber, G. K. Plattner, S. Alin, R. A. Feely, B. Hales, and P. Wheeler (2009), Ocean acidification in the California current system, Oceanography, 22(4), 60-71, doi:10.5670/oceanog.2009.97.

Hoppe, C. J. M. G. Langer, S. D. Rokitta, D. A. Wolf-Gladrow, and B. Rost (2010), On $\mathrm{CO}_{2}$ perturbation experiments: Over-determination of carbonate chemistry reveals inconsistencies, Biogeosci. Discuss., 7(2), 1707-1726, doi:10.5194/bgd-7-1707-2010

Ianson, D., S. E. Allen, S. L. Harris, K. J. Orians, D. E. Varela, and C. S. Wong (2003), The inorganic carbon system in the coastal upwelling region west of Vancouver Island, Canada, Deep Sea Res., Part I, 50(8), 1023-1042, doi:10.1016/S0967-0637(03)00114-6.

Joint, I., M. Inall, R. Torres, F. G. Figueiras, X. A. Álvarez-Salgado, A. P. Rees, and E. M. S. Woodward (2001), Two Lagrangian experiments in the Iberian Upwelling System: Tracking an upwelling event and an offshore filament, Prog. Oceanogr., 51(2-4), 221-248, doi:10.1016/S00796611(01)00068-4.

Kim, H.-C., and K. Lee (2009), Significant contribution of dissolved organic matter to seawater alkalinity, Geophys. Res. Lett., 36, L20603, doi:10.1029/2009GL040271.

Kim, H.-C., K. Lee, and W. Choi (2006), Contribution of phytoplankton and bacterial cells to the measured alkalinity of seawater, Limnol. Oceanogr., 51(1), 331-338, doi:10.4319/lo.2006.51.1.0331.

Koeve, W., H. C. Kim, K. Lee, and A. Oschlies (2011), Potential impact of DOC accumulation on $\mathrm{fCO}_{2}$ and carbonate ion computations in ocean acidification experiments, Biogeosci. Discuss., 8(2), 3797-3827, doi:10.5194/ bgd-8-3797-2011.

Kuffner, I. B., A. J. Andersson, P. L. Jokiel, K. S. Rodgers, and F. T. Mackenzie (2008), Decreased abundance of crustose coralline algae due to ocean acidification, Nat. Geosci., 1(2), 114-117, doi:10.1038/ngeo100.

Langer, G., M. Geisen, K.-H. Baumann, J. Kläs, U. Riebesell, S. Thoms, and J. R. Young (2006), Species-specific responses of calcifying algae to changing seawater carbonate chemistry, Geochem. Geophys. Geosyst., 7, Q09006, doi:10.1029/2005GC001227.

Langer, G., G. Nehrke, I. Probert, J. Ly, and P. Ziveri (2009), Strain-specific responses of Emiliania huxleyi to changing seawater carbonate chemistry, Biogeosciences, 6(11), 2637-2646, doi:10.5194/bg-6-2637-2009.

Levitus, S. (1982), Climatological Atlas of the World Ocean, NOAA, U.S. Dept. of Commer., Rockville, Md.

Lewis, E., and D. W. R. Wallace (1998), Program developed for $\mathrm{CO}_{2}$ system calculations, Carbon Dioxide Inf. Anal. Cent., Oak Ridge Natl. Lab., U.S Dep. of Energy, Oak Ridge, Tenn., doi:10.2172/639712.

Lüthi, D., et al. (2008), High-resolution carbon dioxide concentration record 650,000-800,000 years before present, Nature, 453(7193), 379-382, doi:10.1038/nature06949.

Mehrbach, C., C. H. Culberson, J. E. Hawley, and R. M. Pytkowicz (1973) Measurement of the apparent dissociation constants of carbonic acid in seawater at atmospheric pressure, Limnol. Oceanogr., 18(6), 897-907, doi:10.4319/1o.1973.18.6.0897.

Merico, A., T. Tyrrell, and T. Cokacar (2006), Is there any relationship between phytoplankton seasonal dynamics and the carbonate system? J. Mar. Syst., 59(1-2), 120-142, doi:10.1016/j.jmarsys.2005.11.004

Millero, F. J., K. Lee, and M. Roche (1998), Distribution of alkalinity in the surface waters of the major oceans, Mar. Chem., 60(1-2), 111-130, doi:10.1016/S0304-4203(97)00084-4.

Mittelstaedt, E. (1991), The ocean boundary along the northwest African coast: Circulation and oceanographic properties at the sea surface, Prog Oceanogr., 26(4), 307-355, doi:10.1016/0079-6611(91)90011-A.

Mucci, A. (1983), The solubility of calcite and aragonite in seawater at various salinities, temperatures, and one atmosphere total pressure, Am. J. Sci., 283(7), 780-799, doi:10.2475/ajs.283.7.780.
Mucci, A., M. Starr, D. Gilbert, and B. Sundby (2011), Acidification of lower St. Lawrence Estuary bottom waters, Atmos. Ocean, 49(3), 206-218, doi:10.1080/07055900.2011.599265.

Nightingale, P. D., G. Malin, C. S. Law, A. J. Watson, P. S. Liss, M. I. Liddicoat, J. Boutin, and R. C. Upstill-Goddard (2000), In situ evaluation of air-sea gas exchange parameterizations using novel conservative and volatile tracers, Global Biogeochem. Cycles, 14(1), 373-387, doi:10.1029/1999GB900091.

Omta, A. W., S. Dutkiewicz, and M. J. Follows (2011), Dependence of the ocean-atmosphere partitioning of carbon on temperature and alkalinity, Global Biogeochem. Cycles, 25, GB1003, doi:10.1029/2010GB003839.

Opdyke, B. N., and B. H. Wilkinson (1993), Carbonate mineral saturation state and cratonic limestone accumulation, Am. J. Sci., 293(3), 217-234, doi:10.2475/ajs.293.3.217.

Orr, J. C., et al. (2005), Anthropogenic ocean acidification over the twentyfirst century and its impact on calcifying organisms, Nature, 437(7059), 681-686, doi:10.1038/nature04095.

Pauly, D., and V. Christensen (1995), Primary production required to sustain global fisheries, Nature, 374(6519), 255-257, doi:10.1038/374255a0.

Pierrot, D., E. Lewis, and D. W. R. Wallace (2006), MS Excel program developed for $\mathrm{CO}_{2}$ system calculations, Carbon Dioxide Inf. Anal. Cent Oak Ridge Natl. Lab., U.S. Dep. of Energy, Oak Ridge, Tenn.

Prandke, H., K. Holtsch, and A. Stips (2000), The microstructure/turbulence measuring system MSS, Jt. Res. Cent., Eur. Comm., Ispra, Italy.

Rees, A. P., I. J. Brown, D. R. Clark, and R. Torres (2011), The Lagrangian progression of nitrous oxide within filaments formed in the Mauritanian upwelling, Geophys. Res. Lett., 38, L21606, doi:10.1029/2011GL049322.

Ribas-Ribas, M., J. M. Hernández-Ayón, V. F. Camacho-Ibar, A. CabelloPasini, A. Mejia-Trejo, R. Durazo, S. Galindo-Bect, A. J. Souza, J. M. Forja, and A. Siqueiros-Valencia (2011), Effects of upwelling, tides and biological processes on the inorganic carbon system of a coastal lagoon in Baja California, Estuarine Coastal Shelf Sci., 95(4), 367-376, doi:10.1016/j.ecss.2011.09.017

Ries, J. B., A. L. Cohen, and D. C. McCorkle (2009), Marine calcifiers exhibit mixed responses to $\mathrm{CO} 2$-induced ocean acidification, Geology, 37(12), 1131-1134, doi:10.1130/G30210A.1.

Robinson, C., G. H. Tilstone, A. P. Rees, T. J. Smyth, J. R. Fishwick, G. A Tarran, B. Luz, E. Barkan, and E. David (2009), Comparison of in vitro and in situ plankton production determinations, Aquat. Microb. Ecol., 54(1), 13-34, doi:10.3354/ame01250.

Santana-Casiano, J. M., M. González-Dávila, and I. R. Ucha (2009), Carbon dioxide fluxes in the Benguela upwelling system during winter and spring: A comparison between 2005 and 2006, Deep Sea Res., Part II, 56(8-10), 533-541, doi:10.1016/j.dsr2.2008.12.010.

Soler-Aristegui, I. (2002), The role of the North Atlantic water masses in the draw down of anthropogenic $\mathrm{CO}_{2}, \mathrm{PhD}$ thesis, Univ. of Southampton, Southampton, U. K.

Steinacher, M., F. Joos, T. L. Frölicher, G. K. Plattner, and S. C. Doney (2009), Imminent ocean acidification in the Arctic projected with the NCAR global coupled carbon cycle-climate model, Biogeosciences, 6(4), 515-533, doi:10.5194/bg-6-515-2009.

Stramma, L., S. Hüttl, and J. Schafstall (2005), Water masses and currents in the upper tropical northeast Atlantic off northwest Africa, J. Geophys. Res., 110, C12006, doi:10.1029/2005JC002939.

Stramma, L., P. Brandt, J. Schafstall, F. Schott, J. Fischer, and A. Körtzinger (2008a), Oxygen minimum zone in the North Atlantic south and eas of the Cape Verde Islands, J. Geophys. Res., 113, C04014, doi:10.1029/ 2007JC004369.

Stramma, L., G. C. Johnson, J. Sprintall, and V. Mohrholz (2008b), Expanding oxygen-minimum zones in the tropical oceans, Science, 320(5876), 655-658, doi:10.1126/science.1153847.

Stramma, L., M. Visbeck, P. Brandt, T. Tanhua, and D. Wallace (2009), Deoxygenation in the oxygen minimum zone of the eastern tropical North Atlantic, Geophys. Res. Lett., 36, L20607, doi:10.1029/2009GL039593.

Strickland, J. D. H., and T. R. Parsons (1968), Practical Handbook of Seawater Analysis, Bull. Freshwater Fish. Res. Lab., 167, 311 pp.

Takahashi, T., et al. (2002), Global sea-air $\mathrm{CO}_{2}$ flux based on climatological surface ocean $p \mathrm{CO}_{2}$, and seasonal biological and temperature effects, Deep Sea Res., Part II, 49(9-10), 1601-1622, doi:10.1016/S0967-0645 (02)00003-6.

Thomas, H. (2002), Remineralization ratios of carbon, nutrients, and oxygen in the North Atlantic Ocean: A field databased assessment, Global Biogeochem. Cycles, 16(3), 1051, doi:10.1029/2001GB001452.

Torres, R., et al. (2011), Air-sea $\mathrm{CO}_{2}$ fluxes along the coast of Chile: From $\mathrm{CO}_{2}$ outgassing in central northern upwelling waters to $\mathrm{CO}_{2}$ uptake in southern Patagonian fjords, J. Geophys. Res., 116, C09006, doi:10.1029/ 2010JC006344.

Van Camp, L., L. Nykjaer, E. Mittelstaedt, and P. Schlittenhardt (1991), Upwelling and boundary circulation off northwest Africa as depicted 
by infrared and visible satellite observations, Prog. Oceanogr., 26(4), 357-402, doi:10.1016/0079-6611(91)90012-B.

van Geen, A., R. K. Takesue, J. Goddard, T. Takahashi, J. A. Barth, and R. L. Smith (2000), Carbon and nutrient dynamics during coastal upwelling of Cape Blanco, Oregon, Deep Sea Res., Part II, 47(5-6), 975-1002, doi:10.1016/S0967-0645(99)00133-2.

Wilkerson, F. P., and R. C. Dugdale (1987), The use of large shipboard barrels and drifters to study the effects of coastal upwelling on phytoplankton dynamics, Limnol. Oceanogr., 32(2), 368-382, doi:10.4319/lo.1987.32. 2.0368 .

Wolf-Gladrow, D. A., R. E. Zeebe, C. Klaas, A. Körtzinger, and A. G.

Dickson (2007), Total alkalinity: The explicit conservative expression and its application to biogeochemical processes, Mar. Chem., 106(1-2), 287-300, doi:10.1016/j.marchem.2007.01.006.

Woodward, E. M. S., and A. P. Rees (2001), Nutrient distributions in an anticyclonic eddy in the northeast Atlantic Ocean, with reference to nanomolar ammonium concentrations, Deep Sea Res., Part II, 48(4-5), 775-793, doi:10.1016/S0967-0645(00)00097-7.

Yamamoto-Kawai, M., F. A. McLaughlin, E. C. Carmack, S. Nishino, and K. Shimada (2009), Aragonite undersaturation in the Arctic Ocean: Effects of ocean acidification and sea ice melt, Science, 326(5956), 1098-1100, doi:10.1126/science. 1174190. 